https://doi.org/10.17816/MAJ191S174-76

\title{
EXPERIMENTAL MODEL OF CFS: COGNITIVE, PHYSICAL AND METABOLIC CHARACTERISTICS OF PATHOLOGY DEVELOPMENT
}

\author{
T.A. Filatenkova ${ }^{1}$, S.N. Shanin ${ }^{1}$, E.E. Fomicheva ${ }^{1}$, E.A. Korneva ${ }^{1,2}$, N.B. Serebryanaya ${ }^{1,2,3}$ \\ ${ }^{1}$ Institute of Experimental Medicine, Saint Petersburg, Russia; \\ ${ }^{2}$ Saint Petersburg State University, Saint Petersburg, Russia; \\ ${ }^{3}$ North-Western State Medical University named after I.I. Mechnikov, Saint Petersburg, Russia
}

\section{ЭКСПЕРИМЕНТАЛЬНАЯ МОДЕЛЬ СХУ: КОГНИТИВНЫЕ, ФИЗИЧЕСКИЕ И МЕТАБОЛИЧЕСКИЕ ПОКАЗАТЕЛИ РАЗВИТИЯ ПАТОЛОГИИ}

\author{
Т.А. Филатенкова ${ }^{1}$, С.Н. Шанин ${ }^{1}$, Е.Е. Фомичева ${ }^{1}$, Е.А. Корнева ${ }^{1,2}$, Н.Б. Серебряная $1,2,3$ \\ ${ }^{1}$ ФГБНУ «Институт экспериментальной медицины», Санкт-Петербург; \\ ${ }^{2}$ Санкт-Петербургский государственный университет, Санкт-Петербург; \\ ${ }^{3}$ ФГБОУ ВО «Северо-Западный государственный медицинский университет им. И.И. Мечникова» \\ Минздрава России, Санкт-Петербург
}

In the present study, an analysis of cognitive, behavioral, and metabolic changes during the dynamics of the development of pathology was conducted under an experimental model of chronic fatigue syndrome (CFS). A decrease in physical and research activity of experimental animals indicated the development of fatigue and a depressed emotional state. An increase in the concentration of lactate was also showed, that may indicate a violation of the energy metabolism.

Keywords: chronic fatigue syndrome; behavioral reactions; lactate.

В представленном исследовании проведен анализ когнитивных, поведенческих и метаболических изменений в динамике развития патологии при экспериментальной модели синдрома хронической усталости (СХУ). Показано снижение физической и исследовательской активности, экспериментальных животных, свидетельствующие о развитии утомления и подавленного эмоционального состояния. Так же отмечалось увеличение концентрации молочной кислоты, что может свидетельствовать о нарушении метаболических процессов энергетического обмена.

Ключевые слова: синдром хронической усталости; поведенческие реакции; молочная кислота.

Introduction. Chronic Fatigue Syndrome (CFS) is a poly-symptomatic disease, the main manifestation of which is unmotivated, severe general weakness, accompanied by painful somatic symptom, neuropsychiatric disorders, dysfunctions of the nervous, neuroendocrine and immune systems. Another very important criterion for diagnosis is the absence of any other diseases or pathological processes that can cause the listed symptoms. The exact etiology of this disease is still unknown. One of the most common theories of the onset of CFS is considered a viral infection on the background of chronic stress. At the same time, other theories are being discussed, according to which chronic fatigue syndrome can occur under of psychosocial, immune and infectious dysfunctions [1]. However, the main diagnostic criteria are subjective, and information about them is collected through tests and questionnaires, often filled in by the patient's relatives. Complaints and symptoms of patients may be similar to a number of other diseases, therefore diagnosis is often difficult. The choice of therapy is more complex and symptomatic, that is, aimed not at eliminating the cause of the disease, but only at alleviating the symptoms [2, 3]. Most of the observations, at the moment, are clinical, while experimental studies are rare. The aim of present study was to investigate changes in physical, cognitive activity and the concentration of lactate in the blood serum of animals under an experimental model of chronic fatigue syndrome.

Material and methods. The study was conducted on adult male rats, Wistar, weighing 250-300 g. Immunologically induced model of CFS was based on the intraperitoneal injection of Poly I:C double stranded RNA, polyinosinic:polycytidylic acid - in dose of $3 \mathrm{mg} / \mathrm{kg}$ weight. Registration of fatigue was made by Forced Swimming Test, in which the time of swimming of animals in a cylinder with warm water was measured. For weighting, the load of $10 \%$ animal's weight was placed on backs of animals. The registration of the psycho-emotional status of animals was carried out using the "Open Field" test and the "Elevated plus-maze" test. The registration was carried out within 5 minutes, the analysis was carried out by video recording using the video tracking software VideoMot 2.0 (TSE Systems). After physical exer- 
Table 1

Cognitive, physical and metabolic characteristics of pathology development in rats on the $7^{\text {th }}$ day after Poly I:C injection

\begin{tabular}{|l|c|c|c|c|}
\hline \multirow{2}{*}{} & \multicolumn{2}{|c|}{ Elevated plus maze } & Forced Swimming Test & \multirow{2}{*}{$\begin{array}{c}\text { Concentration } \\
\text { of lactate, mmol/l }\end{array}$} \\
\cline { 2 - 4 } & $\begin{array}{c}\text { Time spent in opened } \\
\text { arm, sec. }\end{array}$ & $\begin{array}{c}\text { Time spent in closed } \\
\text { arm, sec. }\end{array}$ & $\begin{array}{c}\text { Time of swimming, } \\
\text { sec. }\end{array}$ & $3.6 \pm 0.2$ \\
\hline Control animals & $56.0 \pm 0.9$ & $180.0 \pm 10.3$ & $197.7 \pm 29.0$ & 3.0 \\
\hline Animals with experimental CFS & $10.0 \pm 0.5^{*}$ & $241.0 \pm 22.1^{*}$ & $123.3 \pm 14.0^{*}$ & $8.3 \pm 0.8^{*}$ \\
\hline
\end{tabular}

Note. * in compare to control animals; $p<0.05$

cise - swimming with weighting, blood plasma was collected and the concentration of lactic acid was analyzed.

Results and discussion. Analysis of the dynamics of the animals physical activity's changes after injection of Poly $\mathrm{I}: \mathrm{C}$ showed that by the $5-7^{\text {th }}$ day after the administration of the drug, in the experimental group, the level of physical activity decreased significantly. This low level was reliably maintained by the $10^{\text {th }}$ day, after that it was restored to the level in control animals. In the Open Field test, there were no changes in the behavioral reactions of the rats treated with Poly I:C, as well as in the works of T. Katafuchi et al. [4], who explained this fact by the significant influence of the novelty of the situation for animals. However, the additional test - "Elevated plus maze" — indicates that the animals of the experimental group had a higher level of anxiety and less research and physical activity than the animals of the control group had, what may indicate the development of an oppressed emotional state in experimental animals.

Based on the data obtained in behavioral tests on the timing of the most pronounced develop- ment of fatigue, an analysis of the concentration of lactate in the blood plasma of experimental animals was carried out during these period. Especially strongly the concentration of lactic acid increases with forced loads [6]. An increase in the concentration of lactate in the blood of experimental animals was obtained, compared to control animals that were not injected with Poly I:C, but were also subjected to physical exertion. These data correlate with a decrease in physical activity of animals in the test, forced swimming, as well as with the development of symptoms of depression.

Conclusion. Under the conditions of the used CFS model, the concentration of lactate can probably serve as an indirect indicator of an oppressed emotional state development, that is assigned an important role in reducing physical activity. An increase in the concentration of lactate in blood of experimental animals, may also indicate a change in the activity of gluconeogenesis processes, metabolism, and provide the body with energy in general. The work indicates the need to further development of more accurate diagnostic criteria, possibly related to the energy metabolism of the organism.

\section{Reference}

1. Artsimovich NG, Galushina TS. Chronic fatigue syndrome. Moscow: New World; 2002.350 p.

2. James N. A Cronic Fatique Syndrome severity score based on case design criteria. Am J Transl Res. 2013;5(1):53-68.

3. Amoak S. Investigating unexplained CFS. BMC Family Practice. 2016;17:81.

4. Katafuchi T, Kondo T, Yasaka T, et al. Prolonged effects of polyriboinosinic: Induced by fatigue. Neuroscience. 2003;120(3):837-45.

5. Fomicheva EE, Rybakina EG, Filatenkova TA. Activity of the hypothalamic-pituitary-adrenocortical system in the induction of chronic fatigue syndrome in the experiment. Russian Fiziol. Journal im. I.M. Sechenov. 2009;95(1):11-18.

6. George A. Brooks What is glycolysis? Journal of Applied Physiology. 2010;108(6):1450-1451. 